\title{
From the humble wart to HPV: a fascinating story throughout centuries
}

\author{
Marianna Karamanou • Emmanovil Agapitos • \\ Antonis Kousoulis · George Androutsos
}

Received: 2 August 2010/Accepted: 2 August 2010/Published online: 17 August 2010

(C) Springer-Verlag 2010

Nowadays human papillomavirus (HPV) is a significant source of morbidity and mortality worldwide. Epidemiological studies suggest that $75 \%$ of all sexually active people will become infected at some point during their lifetimes [1].

Condylomata acuminata, was a well-known disease at least from the time of Hippocrates (460-370 BC) [2]. Concerning the etymology, the term condyloma derives from ancient Greek and means a round tumor and acuminata comes from the Latin for "sharp points". Myrmecia, a term applied to plantar warts is derived from the Greek word for anthill. In Roman period genital warts were referred to by the terms "ficus" meaning fig because of its resemblance of an open fig and "thymus" from the greek thymion because they looked like the leaves of the plant thyme [3, 4]. A term appeared also in the writings of the Byzantine physician Aetius of Amida (sixth century BC) that mentions: "The term thymus arises from the similarity to the tips of the plant of the same name, which grows in the mountains...It appears in the anus and the pudenda and between the legs" [5]. The term verruca was first used by

M. Karamanou ( $₫)$ · A. Kousoulis · G. Androutsos

History of Medicine Department, Medical School,

University of Athens, 4, str. Themidos, Kifissia,

14564 Athens, Greece

e-mail: mariannakaramanou@yahoo.com

A. Kousoulis

e-mail: antonis.kousoulis@gmail.com

G. Androutsos

e-mail: lyon48@otenet.gr

E. Agapitos

Department of Pathology, Medical School,

University of Athens, Athens, Greece

e-mail: eagapit@med.uoa.gr the German physician Daniel Sennert (1572-1637). In his book entitled Hypomnemata physicae (1636) he points out that they appear on the surface of the skin like the eminences of little hills [6].

At the beginning of the first century AD the Roman physician Aulus Cornelius Celsus in his book De Medecina described three morphologically distinct types of cutaneous warts: (1) the acrochordon which appeared exclusively in children and undergone frequently a spontaneous resolution; (2) the thymion which was a papillomatous and highly vascular lesion that could be developed in the genitalia; and (3) the myrmecia currently known as plantar warts [7]. In ancient Rome it was believed that warts were the result of promiscuous sexual behavior and many satirical poems were written as those in the books Epigrams of the Latin poet Martial (first century AD) [8].

Condylomata acuminata survived the middle ages; in the writings of Lanfranchi (thirteenth century) and Guglielmo da Saliceto (1210-1277) we can find descriptions of genital warts [9]. However, theories about their causation abounded, giving rise to many controversies. The outbreak of syphilis in Europe, at the end of fifteenth century, gave a new interest to genital diseases. Many genital infections as syphilis, gonorrhea and warts were attributed to the same "venereal poison" so well defined centuries later by John Hunter (1728-1793): "The venereal disease arises from a poison which it is produced by the disease and it is capable of again producing a similar disease...it has different powers of contamination... when it is applied to the human body it possesses a power of propagating or multiplying itself" [10]. The "venereal poison" theory led many physicians, including Hunter to regard anogenital warts as a manifestation of syphilis.

In 1712 Daniel Turner (1667-1741), the author of the first book in the English language devoted to dermatology, 
entitled De morbis cutaneis, gives his own explanation for the cause of warts as he believes that they might be "congealed nutritious juices" that had passed from damaged nerve filaments in the skin [11].

The first to recognize that warts comprised a disease entity unrelated to syphilis was the Scottish surgeon Benjamin Bell (1749-1806). Furthermore, he was among the first to describe the appearance of anal cancer in a preexisting condylomatous lesion as he stated: "I have at present a person who had long been liable to piles, who some time ago was attacked with condylomatous excrescences from a venereal taint; to these succeeded a common abscess from inflammation, and last of all the parts have become cancerous" [12].

By the time the idea that correlated warts and syphilis was abandoned and replaced by another erroneous view that linked warts to gonorrhea as nineteenth century physicians' observed that condylomata usually appeared at the end of an attack of gonorrhea and so they called them "gonorrheal warts". However, it is interesting to mention the evolutionary study of Domenico Rigoni-Stern (1810-?), chief physician of a hospital in Verona: on analyzing the death certificates due to cancer in Verona during the period 1760-1839, he found that deaths due to cervical cancer were very rare among virgins and nuns in contrast to married women and widows, linking for the first time cervical cancer with sexual diseases [13].

In the same period some strange suggestions concerning the etiology of warts were made. In 1849, Lancet published an article under the title Peculiar sign describing that "Dr Durr maintained, many years ago, in Hufeland's Journal that females addicted to solitary habits (meaning masturbation) often present with warts on the index or middle finger. Dr Kretschmar, to corroborate this remark, related that a girl, accustomed to search for the near laying of eggs by introducing the index finger into the cloaca of hens, had many warts on that finger" [14]. Also the Viennese dermatologist Ferdinand von Hebra (1816-1880) mentioned in 1874 various other theories concerning warts' etiology as association with animals, repeated irritation of the epidermis, genital discharges, decomposed sebaceous material and he concluded that the "influences causing warts are still very obscure" [15]. In 1879, Albert Neisser (1855-1916) discovered gonococcus, the pathogenic agent of gonorrhea and it became clear that many patients with condylomata showed no signs of gonorrheal infection, putting end to the idea that linked warts to gonorrhea.

The work of Joseph Payne, physician at Saint Thomas Hospital, London, contributed further to the understanding of the contagious nature of common warts. In a paper published in 1891 he described how he developed a wart on his thumb 1 week after scraping lesions from an 11-yearold boy with skin warts; he stated that "common warts appear to arise by the implantation of some contagious material at one or more points of the skin" and he concluded that the etiology of condylomata acuminata and common warts converged [16].

A turning point in the long disputes over etiology was reached in 1893 when the French dermatologist Gémy suggested that condylomata acuminata and common skin warts might be caused by the same pathological agent as there were histological resemblances and many patients with genital warts had warts in their hands [17]. In the following years experiments on the contagiousness began and in 1894 evidences were supplied simultaneously by C. Licht and the Parisian pediatrician Gaston Variot (1855-1930). Licht [18] inoculated material from a wart into his own skin and successfully produced a wart and Variot [19] inoculated the finger of his assistant with fluid from a wart and produced a new lesion.

In 1901, M.L. Heidingsfield linked the oral condylomas with the genital ones. He reported the case of a 24-year-old "puella publica" who was suspected of acquiring genital warts of the tongue as a result of "coitus illegitimus" (oral sex). Heidingsfield performed detailed histological studies of the wart specimens from both the tongue and labia of his patient and concluded that condylomata acuminata of the lips conforms not only in clinical character but also in histological structure to condylomata acuminata of the genital location [20].

In 1907 Dr. Giuseppe Ciuffo demonstrated the viral nature of genital warts by inoculating successfully to the skin, a wart extract that had been filtered through a pore size small enough to exclude bacteria and fungi but not viruses (Berkefeld filter). This suggested that the infecting agent might be a virus and indicated a way of transmission, the inoculation. Ciuffo's [21] results were enough to convince the researchers that the genital warts were not only caused by a virus but this virus was identical to that which caused common warts.

In the following decades a number of major breakthroughs in many aspects of warts research have occurred as the appearance of HPV particles in skin warts [22], the concept of koilocytosis in Pap smears and cervical biopsies [23], the discovery of human papova group [24, 25], the electron microscopic demonstration of HPV particles in genital warts [26, 27], the description of koilocytic atypia as a sign of HPV in flat lesions of the cervix $[28,29]$ and finally the leading discovery of the German virologist Herald zur Hausen (1936-). In 1976, he published the hypothesis that human papilloma virus plays an important role in the cause of cervical cancer [30] and then in 1983 he identified the types HPV16 and HPV18 [31]. A revolutionary work that made possible the development of HPV vaccine, introduced in 2006. For his research zur Hausen received the Nobel Prize in Physiology or Medicine 2008. 
Throughout centuries science has made a remarkable progress both in clinical and therapeutical fields in the study of HPV, a major cause of human pathology. Nowadays concerns have to focus mainly on prevention measures (Pap test, sexual education, vaccination) in order to limit the spread of this highly virulent virus.

Conflict of interest None.

\section{References}

1. Koutsky L (1997) Epidemiology of genital human papillomavirus infection. Am J Med 102:3-8

2. Littré E (1861) Oeuvres complètes d'Hippocrate, vol 10. Baillière, Paris, pp 553

3. Bäfverstedt B (1967) Condylomata acuminate-past and present. Acta Derm Veneorol 47(5):376-381

4. Skinner HA (1961) The origin of medical terms. Williams and Wilkins, Baltimore, pp 121

5. Aetii Amideni (1935) Libri Medicinales. A. Olivieri, Lipsiae, pp 67

6. Sennert D (1636) Hypomnemata physica. Frankfurt, pp 428

7. Celsus AC (1960) De Medicina (transl. by WG Spencer), vol 2, Heinemann, London, pp 160-163

8. Wills G (2008) Martial's epigrams: a selection translated and with an introduction. Viking, New York, pp 206

9. Oriel JD (1971) Natural history of genital warts. Br J Vener Dis $47: 1-13$

10. Hunter J (1810) A treatise on the venereal disease. Bulmer, London, pp 9

11. Turner D (1731) De morbis cutaneis, a treatise of diseases incident to the skin. Walthoe, London, pp 278-280

12. Bell B (1793) A treatise on gonorrhoea virulenta and lues venerea. Watson, Mudie and Murray, Edinburgh, vol 2, pp 100

13. Rigoni-Stern D (1842) Fatti statistici relativi alle malattie cancerose che servivono di base alle poche cose dette dal dottore. Giornale Servire Progresso Patologia i Terapia (Series 2) 2:507-517
14. (1849) Peculiar sign. Medical news. Lancet ii:250

15. von Hebra F (1866) On diseases of the skin including the exanthemata. The new Syndenham society, London, pp 301

16. Payne JF (1891) On the contagiousness of common warts. Br J Dermatol 3:185-188

17. Oriel JD (1971) Anal warts and anal coitus. Br J Vener Dis 47:373-376

18. Licht C (1894) Om Vorters Smitsomhed. Ugeskrift Laeger $1: 368-369$

19. Variot G (1894) Un cas d'inoculation expérimentale des verrues de l'enfant à l'homme. J Clin Therap Infant 2:529-534

20. Heidingsfield ML (1901) Condylomata acuminata lingue (Venereal warts of the tongue). J Cutan Genito-Urinary Dis 19:226-234

21. Ciuffo G (1907) Imnesto positivo con filtrato di verruca volgare. Giorn Ital Mal Venereol 48:12-17

22. Strauss MJ et al (1949) "Crystalline" virus-like particles from skin papillomas characterized by intranuclear inclusion bodies. Proc Soc Expt Biol Med 72:46-50

23. Koss LG, Durfee GR (1956) Unusual patterns of squamous epithelium of the uterine cervix: cytologic and pathologic study of koilocytotic atypia. Ann NY Acad Sci 63(6):1245-1261

24. Melnick JL (1962) Papova virus group. Science. 135:1128-1130

25. Rowson KE, Mahy BW (1967) Human papova (wart) virus. Bacteriol Rev 31(2):110-131

26. Dunn AE, Ogilvie MM (1968) Intranuclear virus particles in human genital wart tissue observations on the ultrastructure of the epidermal layer. J Ultrastruct Res 22(3):282-295

27. Almeida JD, Oriel JD, Stannard LM (1969) Characterization of the virus found in human genital warts. Microbios 3:225-232

28. Meisels A, Fortin R (1976) Condylomatous lesions of the cervix and vagina. I. Cytologic patterns. Acta Cytol 20(6):505-509

29. Purola E, Savia E (1977) Cytology of gynecologic condyloma acuminatum. Acta Cytol 21(1):26-31

30. zur Hausen H (1976) Condylomata acuminata and human genital cancer. Cancer Res 36(2 pt 2):794

31. Boshart M, Gissmann L, Ikenberg H, Kleinheinz A, Scheurlen W, zur Hausen H (1984) A new type of papillomavirus DNA, its presence in genital cancer biopsies and in cell lines derived from cervical cancer. EMBO J 3(5):1151-1157 